\title{
EFFECTS OF POST-EMERGENT HERBICIDES ON Trichoderma harzianum, A POTENTIAL BIOCONTROL AGENT AGAINST Sclerotinia sclerotiorum IN SOYBEAN CROPPING
}

\author{
M. C. ROLLÁN ${ }^{1}$, C. MÓNACO ${ }^{1,2}$, G. LAMPUGNANI ${ }^{1}$, N. ARTETA ${ }^{1}$, \\ D. BAYO ${ }^{2}$ and M. I. URRUTIA ${ }^{1}$ \\ ${ }^{1}$ FACULTAD DE CIENCIAS AGRARIAS Y FORESTALES, UNIVERSIDAD NACIONAL DE LA PLATA,
ARGENTINA; ${ }^{2}$ COMISIÓN DE INVESTIGACIONES CIENTIFICAS DE LA PROVINCIA \\ DE BUENOS AIRES, ARGENTINA
}

Received: 15 September, 2006; accepted: 31 May, 2007

Trichoderma harzianum is a potential biocontrol agent against Sclerotinia sclerotionum in soybean. Information is needed on the compatibility of this biocontrol agent and the postemergent herbicides used in soybean cropping.

Haloxyfop R Methyl (EC 10.4\%), Glyphosate (SL 48\%), Imazamox (WG 70\%) and Imazethapyr (SL 10\%) were evaluated for their effects on the mycelial growth of $T$. harzianum on in vitro agar plates. Glyphosate (2000 ppm), Imazethapyr (500 and $250 \mathrm{ppm}$ ) and Haloxyfop $\mathrm{R}$ Methyl (1000, 500 and $100 \mathrm{ppm})$ reduced the mycelial growth of T. harzianum. Imazamox had no effect at any concentration.

Subsequently, all the herbicides were assessed for their effect on soil populations of $T$. harzianum. Greenhouse assays conducted with non-sterile soil inoculated with T. harzianum and a specific herbicide were sampled before pesticide application and after 30 days. The number of colony forming units per gram of soil (c.f.u./g of soil) was evaluated with a soil dilution technique using Trichoderma selective medium (TSM). No detrimental effect was revealed.

Key words: biocontrol agent, population density, Trichoderma harzianum, soybean stem decay, post-emergent herbicides

\section{Introduction}

Stem decay caused by Sclerotinia sclerotionum is one of the main diseases affecting soybean in Argentina (Distéfano de Vallone and Giorda, 1997; Ploper, 1999). The primary source of inoculum is the sclerotium that survives in the soil. The destruction or inactivation of sclerotia can reduce primary inoculum and might provide a way of controlling this disease (del Río et al., 2002; Budge and Whipps, 2001). 
Many researchers have obtained effective biological control of Sclerotinia diseases using species of Trichoderma as mycoparasites of the sclerotia of $S$. sclerotiorum (Knudsen et al., 1991; Homechin, 1983; Mitidieri and Scandiani, 1989; Illipronti and Machado, 1993; Inbar et al., 1996; Mónaco et al., 1998; Bae et al., 2001; Mc Lean et al., 2001; Elad et al., 2002).

The potential utility of Trichoderma as a biocontrol agent depends largely on its compatibility with agricultural chemicals or other control practices (Papavizas, 1985; Pereira et al., 1996; Nath et al., 2004; Chakraborty et al., 2003). Herbicides are reported to affect the growth and sporulation of Trichoderma spp. in in vitro tests (Dluzniewska, 2003; Macek and Lesnik, 1994; Jayaraj and Radhakrishnan, 2000a; Sesan, 2002; Desai and Srikant, 2004). A variable effect of Glyphosate on soil microflora has been shown in several reports, including reduced bacterial, actinomycete and fungal populations in forest soils (Gorlach-Lira et al., 1997), increased populations of soil actinomycetes and fungi (Araújo et al., 2003), increased soil biomass (Haney et al., 2002) or no long-term change in microbial populations (Busse et al., 2001). Information about the effects of herbicides on the survival of Trichoderma spp. in soil was given by Rao and Divakar (2002), who reported some inhibitory effects with Butachlor and 2,4 D on T. viride, and by Jayaraj and Radhakrishnan (2000b) with Pendimethalin on T. harzianum.

Previous research by Mónaco et al. (1998) was initiated with T. harzianum (strain ThS12) because of its ability to parasitise the sclerotia of S. sclerotiorum. If this strain is to be used for the biological control of soybean stem decay, information on the compatibility of the biological control agent and the agricultural chemicals used in soybean cropping is needed.

The objective of this research was to evaluate the effect of the post-emergent herbicides used in protected soybean crops in Argentina on the mycelium growth on in vitro agar plates and on soil populations of T. harzianum (strain ThS12).

\section{Materials and methods}

Isolates and cultures

Trichoderma harzianum (strain ThS12), used in this study, has been identified as a promising biocontrol agent of Sclerotinia sclerotionum due to its ability to parasitise sclerotia (Mónaco et al., 1998 ). Isolates were grown on $2 \%$ potato dextrose agar (PDA) and stored at $5^{\circ} \mathrm{C}$.

Herbicides

The post-emergent herbicides used are listed in Table 1 (Anonymous, 2001; Tomlin, 1994).

T. harzianum mycelial growth on PDA

Various formulations of the herbicides were analysed on PDA to investigate their effect on the mycelial growth of T. harzianum. 
Table 1

Names and application conditions of the post-emergent herbicides used

\begin{tabular}{|c|c|c|c|}
\hline Common name & Chemical name & $\begin{array}{l}\text { Rate of } \\
\text { application }\end{array}$ & $\begin{array}{l}\text { Type of formulation and } \\
\text { concentration }(\%)\end{array}$ \\
\hline Haloxyfop R Methyl & $\begin{array}{l}\text {-2-(4-((3- chloro -5(trifluoromethyl)-2- } \\
\text { pyridinyl)oxy) phenoxy) propanoic acid methyl) }\end{array}$ & $1.41 / h a$ & EC 10.4 \\
\hline Glyphosate & $\mathrm{N}$-(phosphonomethyl) glycine & $61 /$ ha & SL 48 \\
\hline Imazamox & $\begin{array}{l}\text { 2-(4-isopropyl-4-methyl-5-oxo-2-imidazolin- } \\
\text { 2-yl)-5-methoxymethylnicotinic acid }\end{array}$ & $70 \mathrm{~g} / \mathrm{ha}$ & WG 70 \\
\hline Imazethapyr & $\begin{array}{l}\text { 2-[4,5-dihydro-4-methyl-4-(1-methylethyl)- } \\
\text { 5-oxo- } 1 H \text {-imidazol-2-yl]-5-ethyl-3- } \\
\text { pyridinecarboxylic acid }\end{array}$ & $0.81 / h a$ & SL 10 \\
\hline
\end{tabular}

Doses of herbicides were added to $9 \mathrm{ml}$ of molten PDA to give final concentrations of 2000 , 1000,100 and 10 ppm of Glyphosate, 1000, 500, 100 and 10 ppm of Haloxyfop R Methyl, 500, 250, 100 and $10 \mathrm{ppm}$ of Imazethapyr and 50, 25, 10 and $5 \mathrm{ppm}$ of Imazamox. The highest concentration of each herbicide corresponded to a tenth part of the field rate recommended for Argentina. For the controls, $1 \mathrm{ml}$ of distilled water was added to $9 \mathrm{ml}$ of molten PDA.

The molten PDA was poured into 9-cm diameter Petri dishes and allowed to cool. Cores of mycelia ( $6 \mathrm{~mm}$ diameter) from the leading edge of $T$. harzianum cultures on PDA were placed in the centre of the Petri dishes containing the herbicide treatments and controls.

The plates were incubated at $25^{\circ} \mathrm{C}$ in the dark. After five days of incubation, the diameter of the fungus colonies was measured. Each plate represented one experimental unit. Each treatment consisted of four replications and the experiment was conducted twice.

\section{T. harzianum soil population studies}

Inoculum was prepared by growing the fungus on a substrate containing bran wheat, sand and distilled water $(2: 1: 2 \mathrm{w} / \mathrm{w} / \mathrm{v})$. The substrate was autoclaved for three consecutive days at $120^{\circ} \mathrm{C}$ for 20 minutes. Incubation was carried out in an incubator at $25^{\circ} \mathrm{C}$ in darkness for 20 days.

Silt loam soil was used (clay $21.2 \%$, lime $56 \%$, sand $22.8 \%$; $\mathrm{pH}: 6.4 ; \mathrm{C}: 1.95 \%$; OM \%: 3.35 , moisture $\%: 24.70 \%$ ). The pots were filled with $1 \mathrm{~kg}$ dry soil and amended with wheat bran colonised by $T$. harzianum. The culture medium was crumbled in the soil until a homogeneous mixture was obtained.

Herbicides were applied as a suspension in water, adjusted to the recommended rate of application to the soil surface.

For each treatment the fungus and a selected herbicide were incorporated into the soil in each pot. The controls received only the fungus.

There were five treatments: 1) T. harzianum with Haloxifop R Methyl, 2) T. harzianum with Glyphosate, 3) T. harzianum with Imazethapyr, 4) T. harzianum with Imazamox and 5) control (T. harzianum alone). Each pot represented one experimental unit. Each treatment consisted of four replications and the experiment was conducted twice.

The pots were kept in the greenhouse at a minimum temperature of $10^{\circ} \mathrm{C}$ and a maximum average temperature of $28^{\circ} \mathrm{C}$ for 30 days. Soil moisture was adjusted to $80 \%$ of field capacity by watering the pots periodically.

The treatments were arranged in a completely randomised design.

Soil samples $(50 \mathrm{~g})$ were collected from each pot before pesticide application and after 30 days. 
The samples were dried at room temperature and then stored at $5^{\circ} \mathrm{C}$ for estimating the population density of the fungus.

The population density of the fungus was determined with a soil dilution technique using Trichoderma selective medium (TSM) (Elad et al., 1981). Six plates for each sample were incubated at $25 \pm 2^{\circ} \mathrm{C}$ for a week in darkness. The number of colony forming units per gram of soil (c.f.u./g) was determined.

Data analysis

The data from all the experiments were subjected to analysis of variance and the means were compared using Tukey's test at $95 \%$ probability.

The number of c.f.u./g of soil of T. harzianum from each pot at 30 days was transformed to a percentage of the c.f.u./g of the initial soil (before application of herbicides), taken as $100 \%$.

The percentage values were transformed following the formula:

$$
Z=\operatorname{arcsine}(\text { percentage) } 1 / 2
$$

Since the results of the two experiments under similar conditions were similar, data from only one experiment are presented.

\section{Results and discussion}

T. harzianum mycelial growth on PDA

The results of investigations into the effect of selected herbicides on $T$. harzianum fungus growth are given in Table 2 .

The experiments showed that the effect of the herbicides on the mycelial growth of $T$. harzianum depended on the herbicide and its concentration. Glyphosate (2000 ppm), Imazethapyr (500 and $250 \mathrm{ppm}$ ) and Haloxyfop R Methyl (1000, 500 and $100 \mathrm{ppm}$ ) reduced the mycelial growth of T. harzianum. Imazamox had no effect at any concentration. Furthermore, T. harzianum did not sporulate on medium containing $2000 \mathrm{ppm}$ of Glyphosate.

Similar results showing the unfavourable effect of herbicides on the mycelial growth of fungi of the genus Trichoderma were obtained by Dluzniewska (2003), who found that the herbicides Afalon $450 \mathrm{SC}$ (45\% linuron) and Racer $250 \mathrm{WP}$ (25\% fluorochloride) inhibited the growth of $T$. pseudokoningii, $T$. viride and $T$. harzianum by $67 \%$ and $89 \%$, respectively, in in vitro tests.

Macek and Lesnik (1994) reported that the herbicides Triasulfuron (Logran), Triasulfuron + Fluoroglycofen (Statis) and Primisulfuron (Tell) had various effects on T. longibrachiatum in potato dextrose agar tests. All the herbicides inhibited the mycelial growth of $T$. longibrachiatum at field concentrations, but Tell and Statis stimulated growth at medium and low concentrations. Desai and Srikant (2004) found that the herbicide Glyphosate had a very inhibitory effect on T. harzianum development. 
Table 2

Influence of herbicides on the mycelium growth of T. harzianum (in $\mathrm{cm}, 5^{\text {th }}$ day)

\begin{tabular}{cccccc}
\hline \multirow{2}{*}{ Herbicide } & \multicolumn{5}{c}{ Concentration } \\
\cline { 2 - 6 } & $\mathrm{C} 1$ & $\mathrm{C} 2$ & $\mathrm{C} 3$ & $\mathrm{C} 4$ & Control \\
\hline Glyphosate & $2000 \mathrm{ppm}$ & $1000 \mathrm{ppm}$ & $500 \mathrm{ppm}$ & $100 \mathrm{ppm}$ & $0 \mathrm{ppm}$ \\
& $4.2 \mathrm{a}$ & $9.0 \mathrm{~b}$ & $9.0 \mathrm{~b}$ & $9.0 \mathrm{~b}$ & $9.0 \mathrm{~b}$ \\
E. & $1000 \mathrm{ppm}$ & $500 \mathrm{ppm}$ & $100 \mathrm{ppm}$ & $10 \mathrm{ppm}$ & $0 \mathrm{ppm}$ \\
Haloxyfop R Methyl & $5.0 \mathrm{a}$ & $5.1 \mathrm{a}$ & $6.0 \mathrm{~b}$ & $9.0 \mathrm{c}$ & $9.0 \mathrm{c}$ \\
& $500 \mathrm{ppm}$ & $250 \mathrm{ppm}$ & $100 \mathrm{ppm}$ & $10 \mathrm{ppm}$ & $0 \mathrm{ppm}$ \\
Imazethapyr & $6.0 \mathrm{a}$ & $6.9 \mathrm{a}$ & $9.0 \mathrm{~b}$ & $9.0 \mathrm{~b}$ & $9.0 \mathrm{~b}$ \\
& $50 \mathrm{ppm}$ & $25 \mathrm{ppm}$ & $10 \mathrm{ppm}$ & $5 \mathrm{ppm}$ & $0 \mathrm{ppm}$ \\
Imazamox & $9.0 \mathrm{a}$ & $9.0 \mathrm{a}$ & $9.0 \mathrm{a}$ & $9.0 \mathrm{a}$ & $9.0 \mathrm{a}$ \\
\hline
\end{tabular}

Values are the means of four replicates; Means followed by the same letters are not significantly different at the $\mathrm{P}=0.05$ level

The sporulating and cellulase-producing ability of $T$. harzianum was significantly reduced in in vitro tests by the herbicides Alachlor, Butachlor, 2,4-D, Oxyfluorfen and Pendimethalin, especially at higher concentrations (Jayaraj and Radhakrishnan, 2000a).

\section{T. harzianum population studies}

No significant reduction in the $T$. harzianum population was observed in soil treated with post-emergent herbicides compared with the untreated control (Fig. 1).

Among the herbicides tested, Glyphosate is one of the most widely used because of its effectiveness against many weeds. A high percentage (95-98\%) of the soybean acreage in Argentina is planted with transgenic glyphosate-tolerant soybean cultivars (Anonymous, 2002). Farmers adopted this new technology due to the efficacy of Glyphosate against a wide range of weed species. Variable effects of Glyphosate on soil microflora have been shown by Gorlach-Lira et al. (1997), Araújo et al. (2003), Haney et al. (2002) and Busse et al. (2001). The present results are in line with those reported by Busse et al. (2001), who found that Glyphosate was toxic to bacteria and fungi when grown in soil-free media, but this toxicity was not expressed when Glyphosate was added directly to soil. These authors suggest that artificial medium assays are of limited relevance in predicting Glyphosate toxicity to soil organisms and that field rate applications of Glyphosate should have little or no effect on soil microbial communities. The differences between artificial media and field soil are believed to be due to the polar nature of the Glyphosate molecule and its adsorption to soil particles. 


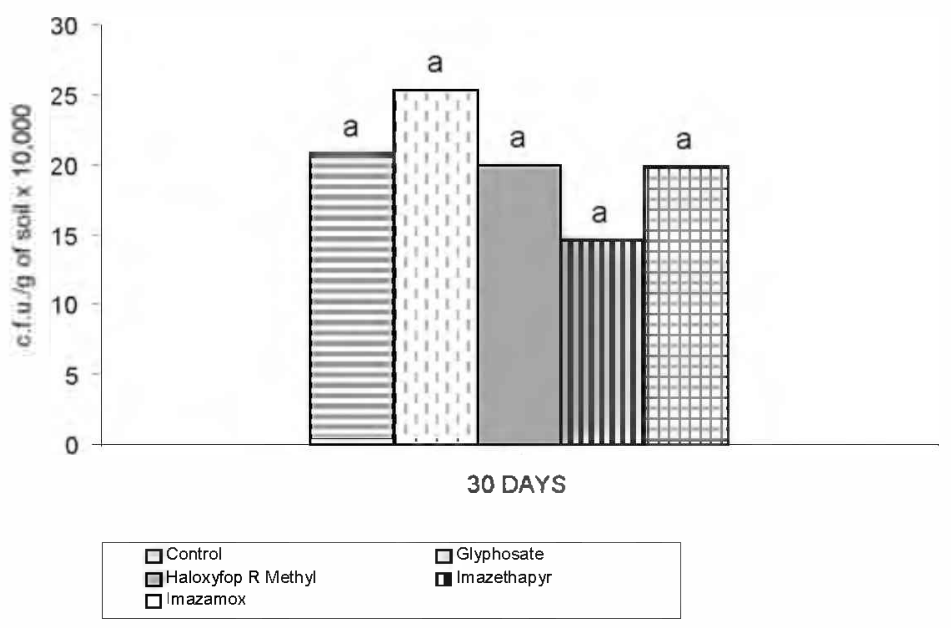

Fig. 1. Trichoderma harzianum population in soil in the presence of herbicides

Imazethapyr and Haloxyfop R Methyl behaved similarly to Glyphosate and are also weakly to moderately adsorbed on the soil (Ahrens, 1994). These results are also in agreement with Mc Lean et al. (2001), who stated that it is unlikely that the level of direct contact observed between fungus and pesticide in the in vitro assay would occur in a field environment, given the strong buffering capacity of the soil.

In vitro agar plate experiments are useful to determine the potential tolerance of fungi to pesticides, but assessing the compatibility between a biocontrol agent and pesticides in natural environments would provide a more reliable measure of compatibility.

The development of Integrated Pest Management requires knowledge of the impact of a selected pesticide not only on its intended target but also on other species, including beneficial microorganisms. T. harzianum (THS12) has antagonistic properties against $S$. sclerotiorum, as has been demonstrated in previous research (Mónaco et al., 1998). The results of these investigations show that this strain can survive in soil treated with Glyphosate and other selected post-emergent herbicides currently used to protect soybean crops in Argentina.

\section{References}

Anonymous (2001): Guia de Productos Fitosanitarios para la República Argentina. Cámara de Sanidad Agropecuaria y Fertilizantes, 1600 pp. 
Anonymous (2002): El quinquenio de la soja transgénica. Secretaría de Agricultura, Ganadería, Pesca y Alimentos. 22 pp. Available online: www.sagpya.mecon.gov.ar

Araújo, A. S. F., Monteiro, R. T. R., Abarkeli, R. B. (2003): Effect of glyphosate on the microbial activity of two Brazilian soils. Chemosphere, 52, 799-804.

Ahrens, W. H. (1994): Herbicide Handbook. $7^{\text {th }}$ Edition. Weed Science Society of America, Champaign, IL, $352 \mathrm{pp}$.

Bae, Y. S., Park, K., Knudsen, G. R. (2001): Effect of sclerotial distribution pattern of Sclerotinia sclerotiorum on colonizing ability of Trichoderma harzianum. Microbiology, 29, 54-57.

Budge, S. P., Whipps, J. M. (2001): Potential for integrated control of Sclerotinia sclerotionum in glasshouse lettuce using Coniothyrium minitans and reduced fungicide application. Phytopathology, 91, 221-227.

Busse, M. D., Ratcliff, A. W., Shestak, C. J., Powers, R. F. (2001): Glyphosate toxicity and the effects of long term vegetation control on soil microbial communities. Soil Biology and Biochemistry, 33, $1777-1789$.

Chakraborty, U., Sarkar, B., Chakraborty, B. N. (2003): Protection of soybean root rot by Bradyrhizobium japonicum and Trichoderma harzianum, associated changes in enzyme activities and phytoalexin production. Journal of Mycology and Plant Pathology, 33, 21-25.

Del Río, L. E., Martinson, C. A., Yang, X. B. (2002): Biological control of Sclerotinia stem rot of soybean with Sporidesmium sclerotivorum. Plant Disease, 86, 999-1004.

Desai, S. A., Srikant, K. (2004): Effect of fungicides, insecticides and weedicides on the growth and sporulation of native Trichoderma harzianum Riffai. Karnataka Journal of Agricultural Science, 17, 57-62.

Distéfano de Vallone, S., Giorda, L. M. (1997): Enfermedades de la soja en la Argentina. Instituto Nacional de Tecnología Agropecuaria (INTA), Centro regional Córdoba, Argentina, 72 pp.

Dluzniewska, J. (2003): Reaction of fungi of Trichoderma genus to selected abiotic factors. Electronic Journal of Polish Agricultural Universities, Agronomy, 6, Issue 2. Available online: http://www.ejpau.media.pl

Elad, Y., Chet, I., Henis, Y. (1981): A selective medium for improving quantitative isolation of Trichoderma spp. from soil. Phytoparasitica, 9, 59-67.

Elad, Y., Bhardwaj, S., Nitzani, Y., Rav-David, D. (2002): Biocontrol of Sclerotinia sclerotionum by Trichoderma spp. resistance-inducing isolates as modified by spatial, temporal and host plant factors. Bulletin-OILB/SROP, 25, 17-20.

Gorlach-Lira, K., Stefaniak, O., Slizak, W., Owweedyk, I. (1997): The response of forest soil microflora to the herbicide formulations Fusilade and Roundup. Microbiological Research, $152,319-329$

Haney, R. L., Senseman, S., Hons, F. M. (2002): Effect of Roundup Ultra on microbial activity and biomass from selected soils. Joumal of Environmental Quality, 31, 730-735.

Homechin, M. (1983): Controle biológico de patógenos de Soja. In: Resultados de Pesquisa de soja 1982-83. EMBRAPA Centro Nacional de Pesquisa de Soja, pp. 184-185.

Illipronti, R. A. Jr., Machado, J. (1993): Antagonismo de fungos a Sclerotinia sclerotionum em soja e feijâo. Fitopatologia Brasileira, 18, 162-166.

Inbar, J., Méndez, A., Chet, I. (1996): Hyphal interaction between Trichoderma harzianum and Sclerotinia sclerotionum and its role in biological control. Soil Biology and Biochemistry, 28, 757-763.

Jayaraj, J., Radhakrishnan, N. V. (2000a): Tolerance of Trichoderma harzianum to certain herbicides in vitro. Indian Journal of Weed Science, 32, 74-76 
Jayaraj, J., Radhakrishnan, N. V. (2000b): Survival of the biocontrol agent Trichoderma harzianum in soil as influenced by certain herbicides. Indian Journal of Weed Science, 32, 116-117.

Knudsen, G. R., Eschen, D. J., Dandurand, L. M., Bin, L. (1991): Potential for biocontrol of Sclerotinia sclerotionm through colonization of sclerotia by Trichoderma harzianum. Plant Disease, $\mathbf{7 5}$, $466-470$

Macek, J., Lesnik, M. (1994). The influence of primi- and triasulfuron herbicides on mycelial growth and sporulation of some parasitic soil fungi. Joumal of Plant Diseases and Protection, 101, 492-497.

Mc Lean, K. L., Hunt, J., Stewart, A. (2001): Compatibility of the biological control agent Trichoderma harzianum C52 with selected fungicides. New Zealand Plant Protection, 54, 8488.

Mitidieri, I. Z., Scandiani, M. M. (1989): Efecto del tratamiento con Trichoderma spp. sobre la producción de apotecios y degradación de esclerocios de Sclerotinia sclerotionum. In: Programs and Abstracts of the World Soybean Research Conference IV. Buenos Aires, Argentina, $\mathrm{p} 105$.

Mónaco, C., Rollán, M. C., Nico, A. (1998): Efecto de micoparásitos sobre la capacidad reproductiva de Sclerotinia sclerotionim. Revista Iberoamericana de Micologia, 15, 84-87.

Nath, S., Das, B. C., Sarmah, D. K. (2004): Management of white rot (Sclerotinia sclerotionum) of French bean (Phaseolus vulgare) with carrier based formulation of Trichoderma harziamum. Indian Joumal of Agricultural Sciences, 74, 168-170.

Papavizas, G. C. (1985): Trichoderma and Gliocladium: Biology, ecology and potential for biocontrol. Annual Review of Phytopathology, 23, 23-54.

Pereira, J., Chaves, G., Zambilin, L., Matsuoka, K., Silva-Acuña, R., Ribeiro do Vale, F. (1996): Controle integrado de Sclerotinia sclerotiorum. Fitopatologia Brasileira, 21, 254-260.

Ploper, D. L. (1999): Management of economically important diseases on soybean in Argentina. Proceedings of the World Soybean Research Conference VI, Chicago, Illinois, USA, pp. 269280.

Rao, C. V. R., Divakar, B. J. (2002): Effect of three pesticides on the fungal bioagent, Trichoderma viride. pp. 183-186. In: Manoharachary, C., Purohit, D. K., Ram Reddy, S., Singara Charya, M. A., Girisham, S. (eds.), Frontiers in Microbial Biotechnology and Plant Pathology. Prof. S. M. Reddy Commemoration Volume. Scientific, Jodhpur.

Sesan, T. E. (2002): The in vitro biological action of pesticides on the biocontrol agent Trichoderma viride. Biological Control of Fungal and Bacterial Plant Pathogens. IOBC wprs Bulletin, 25, $415-418$

Tomlin, C. (1994): The Pesticide Manual, Incorporating a Pesticide Handbook, Tenth edition. Crop Protection Publications, $1341 \mathrm{pp}$.

Corresponding author: M. C. Rollán

Phone : 00542214236758

E-mail: fitopato@ceres.agro.unlp.edu.ar 